\title{
PREVALENCE OF CRYPTOSPORIDIOSIS IN CROSSBRED CALVES IN TWO SELECTED AREAS
} OF BANGLADESH

\author{
A. Khair ${ }^{1}$, M. M. Alam ${ }^{1}$, A. K. M. A. Rahman ${ }^{1}$, M. Shahiduzzaman², \\ M. S. Parvez ${ }^{3}$ and E. H. Chowdhury ${ }^{4 *}$ \\ ${ }^{1}$ Department of Medicine, ${ }^{2}$ Department of Parasitology, ${ }^{3}$ Department of Microbiology and Hygiene, ${ }^{4}$ Department of \\ Pathology, Faculty of Veterinary Science, Bangladesh Agricultural University, Mymensingh- 2202, Bangladesh
}

\begin{abstract}
A cross-sectional study was conducted to determine the prevalence of bovine cryptosporidiosis using 110 fecal samples of crossbred diarrhoeic calves from two different areas (Muktagacha, Mymensingh and Shajadpur, Sirajgonj) in Bangladesh during April 2012 to September 2014. The fecal samples were screened by rapid detection kit and confirmed by Modified Ziehl- Neelsen staining, and polymerase chain reaction (PCR). The positive samples along with standard positive control yielded 1325bp band on PCR. The overall prevalence of cryptosporidiosis in crossbred calves was $28.18 \%$ (31/110) by rapid detection kit. The higher prevalence of cryptosporidiosis was found in the calves from Shajadpur $(29.76 \%)$ than the calves from Muktagacha $(23.08 \%)$. The prevalence of cryptosporidiosis was significantly $(\mathrm{p}<0.001)$ higher in calves between $1-2$ months $(70 \%)$ age group than less than one month age group (24.49\%). Cryptosporidiosis was not observed in calves over two months age. The prevalence of cryptosporidiosis was higher in males $(34.75 \%)$ than females $(24.64 \%)$ although not significant statistically. It is evident that the prevalence of cryptosporidiosis in bovine in these areas is under diagnosed and the clinical status of infection is potentially high.
\end{abstract}

Key words: Cryptosporidiosis, Prevalence, Calves, Oocysts,

\section{INTRODUCTION:}

Cryptosporidiosis is an emerging zoonotic disease of global importance caused by the apicomplexan protozoan parasite which is one of the most common causes of diarrhea in humans and livestock worldwide. Oocysts of cryptosporidium are usually transmitted by the feco-oral route, through direct host-to-host contact, and indirect contamination of food or water (Sayers et al., 1996). The zoonotic transmission has been confirmed by epidemiological studies involving pets, farm animals and by accidental infection of veterinary workers (Ahmed., 1984; Webster, 1993; Casemore et al., 1997; Saini et al., 2000; Nydam et al., 2005; Collick et al., 2006). Ruminants are reported to be the major source of Cryptosporidium (C.) parvum transmission to humans (Xiao et al., 2004a, b; Caccio, 2005). Cryptosporidium spp. infection is well known as a major cause of morbidity and mortality particularly in immune compromised hosts and young animals (Graff et al., 1999). It causes self-limited watery diarrhoea in immunocompetent subjects but has far more devastating effects on immunocompromised patients and in some cases can be life threatening due to dehydration caused by chronic diarrhea (Alves et al., 2001; Mohandas et al., 2002; Caccio et al., 2005; Chen et al., 2005).In livestock the disease may lead to economic loss due to mortality, retarded growth of the animals, cost of drugs, veterinary assistance and increased staff labor (De Graaf et al., 1999). It has been reported as an important cause of calf mortality (Moon et al., 1982; Tzipori et al., 1982; Hoffman and Sandoval, 1989). Cryptosporidium oocysts may remain viable in water for over 140 days and are very resistant to the most common disinfectants making them difficult to destroy by conventional chlorination treatment (Ahmed, 1984).

Cryptosporidiosis is considered as the third major cause of diarrheal disease worldwide (Janoff and Reller, 1987; Casemore et al., 1997; Fayer et al., 1997, 2000; Morgan et al., 1999; Spano and Crisanti, 2000). Cryptosporidiosis in cattle has been reported from different parts of the world with prevalence ranging from $24.5 \%$ to $45.5 \%$ (Kumar et al., 2005). The calf mortality in Bangladesh up to 12 months of age was reported from $9 \%$ under rural (Debnath et al., 1990) to $13.4 \%$ under a farm (Debnath et al., 1995) conditions. Reports on entero-pathogens associated with calf diarrhea are very limited from Bangladesh (Samad et al., 1977, 2001). There is no published report on the prevalence of cryptosporidiosis in crossbred calves in Bangladesh. This study describes the prevalence of cryptosporidiosis in crossbred calves under large and small holder dairy farms in some selected areas of Bangladesh

*Corresponding e-mail address: emdad001@yahoo.com

Copyright @ 2014 Bangladesh Society for Veterinary Medicine

All rights reserved 0309/2014 


\section{Khair A and others}

\section{MATERIALS AND METHODS}

\section{Study areas, period and population}

Shahjadpur Upazilla of Sirajgonj District and Muktagacha Upazilla of Mymensingh District in Bangladesh, the most important dairy zone of Bangladesh were selected as study area. Five hundred (500) farms having at least two cross-bred dairy cattle were selected conveniently. Calves from day old to 1 year of age were included in this study. Active monitoring and surveillance system was used to collect sample from the selected farms over a period of 30 months from April 2012 to September 2014.

\section{Faecal sample collection and examination}

A total of 110 faecal samples from diarrhoeic calves of research area (Muktagacha and Shajadpur) were collected and examined for the presence of Cryptosporidium. Fecal samples were collected directly from the rectum of the animals or from the faecal mass immediately after defecation in stool pot with detail history of age group and sex and were immediately capped, labeled accordingly which included sample identification and site of collection. The collected samples were placed on ice in an insulated container in order to maintain low temperature of the samples. Feces were transported to the Laboratory of Department of Medicine, Bangladesh Agriculture University, Mymensingh and processed within 1-3 days of collection. The samples were examined in the field and in the Laboratory soon after collection or after preservation by freezing at $-20^{\circ} \mathrm{C}$. In this study, stool samples collected from diarrheic calves were tested by rapid detection kit (Rainbow Calf scour 5, BioX Diagnostics, Belgium) to detect Cryptosporidium and other enteropathogens from diarrheal fecal samples as per manufacturer's instruction(Fig.1). A total of 4 representative samples from 31 positive for cryptosporidiosis by BioK-306 were mixed together and a thin smear was prepared and stained using a modified Ziehl-Neelsen method for further confirmation of Cryptosporidium spp (Fig-2). Samples were treated with carbol-fuchsin solution for 3 minutes recommended by Lennette et al., 1985. The discoloration procedure was realized with discoloration solution $(95 \%$ ethyl alcohol-50ml and $95 \%$ Acetone-50ml) for $15-20$ seconds used instead of the ethyl alcohol-sulfuric acid 5\% recommended by Henriksen and Polhenz (1981). These modifications promoted a better washing out of the excess of carbol fuchsin therefore increasing the dye efficiency. In such conditions, the visualization of protozoan oocysts on the slides examined became easier. Smears were washed with running water and counterstained with solution of $0.4 \%$ malachite green or methylen blue at $1 \%$ for 1 minute. After the final wash with water, slides were dried at room temperature and then examined using X40 and X100 magnification under microscope. The positive samples were stored at $-20^{\circ} \mathrm{C}$ for DNA extraction.

\section{DNA Extraction}

DNA was extracted from concentrated mixture of 4 positive samples. Cryptosporidium oocysts were purified using a $\mathrm{NaCl}$ flotation procedure. Purified oocysts were washed three times in DDW/PBS in 50ml tube. After wash, the sediment was re-suspended with $45 \mathrm{ml}$ saturated salt solution. Five milliliter DDW was layered above the re-suspended samples. Samples were then centrifuged at 2300rpm for 30 minutes without break. Cryptosporidium oocysts were deposited in the upper layer and were collected and transferred to another tube by pipette. The oocysts were then subjected to 5-8 freeze-thaw cycles and DNA extraction was carried out using a Promega DNA extraction kit according to the manufacturer's instructions. The DNA extracted from the concentrated oocyst was used for polymerase chain reaction (PCR). The amplified products obtained from PCR assay were visualized after running through agarose gel electrophoresis.

\section{Cryptosporidium detection by PCR}

Cryptosporidium oocysts were confirmed by polymerase chain reaction (PCR). Primary PCR was performed by primers SSU-F2: (5 TTCTAGAGCTAATACATGCG 3) and SSU-R2: (5'-CCCATTTCCTTCGAAACAGGA 3) (Xiao et al.,1999; Limor et al., 2002; Park et al., 2006; Schindler et al., 2005). The primary PCR mixtures contained $5 \mu \mathrm{l}$ of template, $2 \mathrm{X}$ PCR Master mix (Promega, USA)-12.5 $\mu 1,1 \mu \mathrm{l}$ of each primer $(10 \mathrm{pmol} / \mu \mathrm{l})$ and DDW-5.5 $\mu 1$ in a $25 \mu 1$ reaction volume. Thermocycling parameters were 3 minutes at $94^{\circ} \mathrm{C}$ hot start (initial heat activation step), followed by 35 cycles of 45 seconds at $94^{\circ} \mathrm{C}, 45$ seconds at $55^{\circ} \mathrm{C}$ and 1 minute at $72^{\circ} \mathrm{C}$, with a final extension of 7 minutes at $72^{\circ} \mathrm{C}$ (Xiao et al., 1999). The PCR product was loaded on $1.5 \%$ agarose gel, electrophoresis was done for 1 hour. The gel was stained with ethidium bromide and the products (1325bp) were visualized under a UV transilluminator. 


\section{Statistical analysis}

The association of cryptosporidiosis with other variable like area, age and sex were assessed by Chi-square test. The Chi-square test and 95\% confidence interval of prevalence were performed in $\mathrm{R}$ 3.1.0 (The R foundation for Statistical Computing).

\section{RESULTS AND DISCUSSION}

A total of 110 fecal samples from diarrhoeic calves were examined where 31 samples were positive for Cryptosporidium spp. by rapid detection kit (Biok-306). Cryptosporidium spp oocysts were observed in stained smear (Fig. 2). The positive samples along with positive control yielded 1325bp (Fig. 3) band on visualization which was supported by earlier report (Hassanain et al., 2011). The overall prevalence of cryptosporidiosis in calves below six months of age was $28.18 \%$ (Table 1 ).

Prevalence of Cryptosporidiosis was higher in Shajadpur (29.76\%) in comparison to that in Muktagacha (23.08\%). However, this difference was not significant statistically (Table 1). Based on the results of our study, it is evident that bovine cryptosporidiosis is endemic and locally widespread in Bangladesh. Some studies have shown that Cryptosporidium oocysts are able to survive for extended periods in faeces and environment, and very low dose of viable oocysts can cause an infection (Chako et al.,2010). The apparent variability of prevalence between geographical localities may reflect differences in the levels of calf management practices employed at farm level, housing-related factors (i.e., single housed calves, cleanness of the calf sleeping places), calf-related factors at a time of sampling (diarrhoeic versus nondiarrhoeic), nature of the study (cross-sectional versus prospective longitudinal studies), and fecal screening technique used (EL-Shazly et al., 2002; Kaushik et al.,2008).The prevalence of cryptosporidiosis was significantly $(\mathrm{p}<0.001)$ higher in calves between $1-2$ months of age $(70 \%)$ in comparison to those of one month of age $(24.49 \%)$. This finding is also supported by other authors (Swai and Schoonman, 2010; Maldonado-Camargo et al., 1998; Gow and Waldner, 2006; Paul et al., 2008). Several authors reported higher prevalence among calves less than 6 months of age (Ongerth and Etibbs 1989; Shovamoni 2005; Jayabal and Ray 2005; Roy et al. 2006; Mehdizami 2007). The prevalence of cryptosporidiosis did not vary significantly according to sex of calves as also reported by others (Rehman et al., 1985; Shovamani, 2005). However, Nouri and Toroghi (1991) recorded a higher infection in male diarrheic calves than in female calves.

Table 1. Prevalence of cryptosporidiosis in crossbred calves

\begin{tabular}{|llllll|}
\hline & Variable & Tested & Positive & Prevalence (\%) & 95\% Confidence Interval \\
\hline Area & Muktagacha & 26 & 6 & 23.08 & $8.97-43.65$ \\
& Shajadpur & 84 & 25 & 29.76 & $20.27-40.73$ \\
Age & & & & \\
& Upto1 month & 98 & 24 & 24.49 & $16.36-34.21$ \\
& $\begin{array}{l}\text { More than 1 to } 2 \\
\text { months }\end{array}$ & 10 & 7 & 70.0 & $34.75-93.32^{* *}$ \\
& $\begin{array}{l}\text { More than 2 } \\
\text { months }\end{array}$ & 3 & & & $0-70.76^{*}$ \\
Gender & Male & 41 & & & $20.08-50.59$ \\
& Female & 69 & 14 & 34.15 & $15.05-36.49$ \\
\hline Overall & & & & 24.64 & \\
\hline
\end{tabular}

$* 97.5 \%$ confidence interval $* *$ Significant at $\mathrm{p}<0.001$ 
Khair A and others

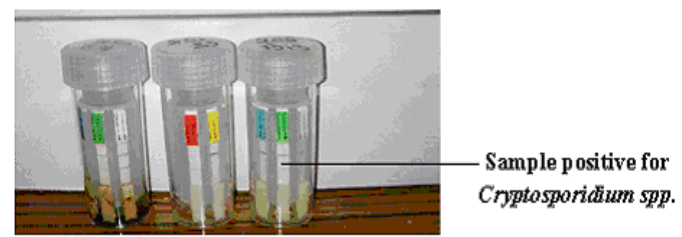

Figure 1. Rainbow Calf Scour 5 (Bio K306

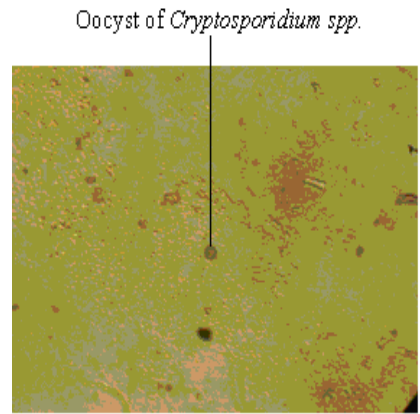

Figure 2. Cryptosporidium spp Oocyst

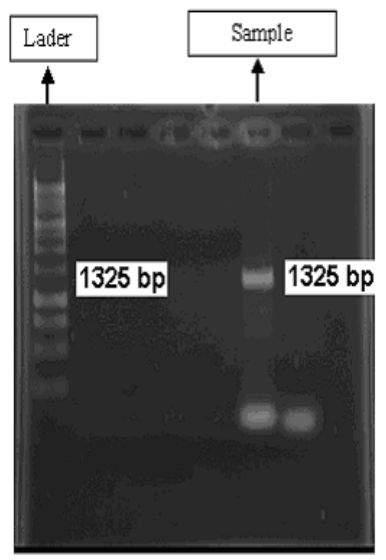

Figure 3. PCR result of Cryptosporidium spp

\section{CONCLUSIONS}

Results of this study indicate that the prevalence of cryptosporidiosis in crossbred calves in these areas is under diagnosed and the clinical status of infection is potentially high. The prevalence of the Cryptosporidium species/genotypes appeared to be age related. Because calves less than 3 months of age are the predominant population infected with C. parvum (zoonotic species), any effort designed to control this infection must be directed primarily at this age group.

A further prospective study, capturing seasonal variations to elucidate the magnitude of the disease (mortalities and reduced production), is desirable. Moreover, studies to understand the dynamics of transmission cycles and the genetic diversity of Cryptosporidium spp. on the farms should be undertaken.

\section{ACKNOWLEDGEMENTS}

The authors thank Krishi Gobeshona Foundation, BARC, Farmgate, Dhaka for funding of this research.

\section{REFERENCES}

1. Ahmed JU (1984). An abattoir survey of female reproductive disorders in cattle in Sweden. Bangladesh Veterinary Journal 18: 55-58.

2. Alves M., Matos O, Fonseca I, Delgado E, Lourenco A and Antunes F (2001). Multilocus genotyping of Cryptosporidium isolates from human HIVinfected and animal hosts. Journal of Eukaryotic Microbiology. Suppl., 17S-18S.

3. Caccio SM (2005). Molecular epidemiology of human cryptosporidiosis. Parasitologia. 47:185-192

4. Casemore DP, Wright S.E and Coop R.L, (1997). Cryptosporidiosis - human and animal epidemiology. In: Fayer, R. (Ed.), Cryptosporidium and Cryptosporidiosis. CRC Press, Boca Raton, FL, pp. 65-92.

5. Chako CZ, Tyler JW, Schultz LG, Chiguma L and Beerntsen BT (2010). Cryptosporidiosis in people: it's not just about the cows," Journal of Veterinary Internal Medicine 24(1): 37-43. 
6. Chen XM, O'haraSP, Huang BQ, Splinter PL, Nelson JB and Larusso NF (2005). Localized glucose and water influx facilitates cryptosporidium parvum cellular invasion by means of modulation of host-cell membrane protrusion. Proclamation of National Academy of Sciences, USA. 102: 6338-6343.

7. Collick AS, Fogarty EA, Zieglar PE, Walter MT, Bowman, DD and Steenhuis TS (2006). Survival of Cryptosporidium parvum oocysts in calf housing facilities in the New York City water sheds. Journal of Environmental Quality, 35: 680-687.

8. Debnath NC, Sil BK, Selim SA, Prodhan MAM and Howlader MMR (1990). A retrospective study of calf mortality and morbidity on smallholder traditional farms in Bangladesh. Preventive Veterinary Medicine. 9: 1-7.

9. Debnath NC, Taimur MJFA, Saha AK, Ersaduzzaman M, Helaluddin M, Rahman ML, Roy DK and Islam MA (1995). A retrospective study of calf losses on the central dairy cattle breeding station in Bangladesh. Preventive Veterinary Medicine. 14: 43-53.

10. El-Shazly AM A, Gabr, Mahmoud MSE, Aziz SSA and Saleh WA (2002). The use of Ziehl-Neelsen stain, enzyme-linked immunosorbent assay and nested polymerase chain reaction in diagnosis of cryptosporidiosis in immunocompetent, - compromised patients. Journal of the Egyptian Society of Parasitology 32(1): 155-166.

11. Fayer R, Morgan U and Upton SJ (2000). Epidemiology of Cryptosporidium: transmission, detection and identification. International Journal for Parasitology 30: 1305-1322.

12. Fayer R, Speer CA and Dubey JP (1997). The general biology of Cryptosporidium. In: Fayer, R. (Ed.), Cryptosporidium and Cryptosporidiosis. CRC Press, Boca Raton, FL, pp. 1-42.

13. Gow $\mathrm{S}$ and Waldner $\mathrm{C}$ (2006). An examination of the prevalence of and risk factors for shedding of Cryptosporidium spp. and Giardia spp. in cows and calves from western Canadian cow calf herds. Veterinary Parasitology, 137(1-2): 50-61.

14. Graaf CE, Vanopdenbosch M, Mora O, Abbassi H and Peters E (1999). A review of the importance of cryptosporidiosis in farm animals. International Journal for Parasitology. 29:1269-1287.

15. Hassanain MA, Fathia A, Khalil M, AbdEL-Razik KA and Shappan RM (2011). Prevalence and molecular discrimination of Cryptosporidium parvum in calves in Behira province, Egypt. Research Journal of Parasitology 6(3):101-108.

16. Henriksen SA and Pohlenz JFL (1981) - Staining of cryptosporidia by a modified Ziehl-Neelsen technique. Acta Veterinaria Scandinavica 22: 594-596, 1981.

17. Hoffman KA and Sandoval SI (1989). Cryptosporidiosis. Vet. Technol. 10, 124.

18. Janoff EN and Reller LB (1987). Cryptosporidium Species, a protean protozoan. Journal of Clinical Microbiology 25: 967-75.

19. Jayabal, L and Ray DD (2005): Cryptosporidial infection in cattle and buffaloes. Journal of Veterinary Parasitology. 19: 165-166.

20. Kaushik K, Khurana S, Wanchu A and Malla N (2008). Evaluation of staining techniques, antigen detection and nested PCR for the diagnosis of cryptosporidiosis in HIV seropositive and seronegative patient. Acta Tropica, 107(1): $1-7$.

21. Kumar D, Sreekrishnan R and Das SS (2005): Cryprosporidiosis: an emerging disease of zoonotic importance. Procedings of the National Academy of Sciences, India, 75:160-172.

22. Lennette EH, Balows A, Hausler WJ and Truant JP (1985) - Manual of Clinical Microbiology. $4^{\text {th }}$ ed. Washington, American Society for Microbiology.

23. Limor JR, Lal AA and Xiao L (2002). Detection and differentiation of Cryptosporidium parasites those are pathogenic for humans by realtime PCR. Journal of Clinical Microbiology, 40 (7): 2335-8.

24. Maldonado-Camargo S, Atwill ER, Saltijeral-Oaxaca JA and Herrera-Alonso LC (1998). Prevalence of and risk factors for shedding of Cryptosporidium parvum in Holstein Freisian dairy calves in central Mexico. Preventive Veterinary Medicine: 36(2): 95-107

24. Mehdiazami M (2007): Prevalence of Cryptosporidium infection in cattle in Isfahan, Iran. Journal of Eukaryotic Microbiology, 54: 100-102.

25. Mohandas K, Sehgal R, Sud A and Malla N (2002). Prevalence of intestinal parasitic pathogens in HIVseropositive individuals in Northern India. Japanese journal of infectious diseases. 55: 83-84.

26. Moon HW, Schwartz A, Welch MJ, McCann PP and Runnels PL (1982). Experimental fecal transmission of human cryptosporidia to pigs and attempted treatment with an ornithine decarboxylase inhibitor. Veterinary Pathology 19: 700-707.

27. Morgan UM, Xiao L, Fayer R, Lal AA and Thompson RCA (1999). Variation in Cryptosporidium: towards a taxonomic revision of the genus. International Journal for Parasitology 29: 1733-1751. 
28. Nouri, M and Toroghi R (1991): Asymptomatic cryptosporidiosis in cattle and humans in Iran. Veterinary Record 128: 358-359.

29. Nydam DV, Lindergard G, Santucci F, Schaaf SL, Wade SE and Mohammed HO (2005). Risk of infection with Cryptosporidium parvum and Cryptosporidium hominis in dairy cattle in the New York City watershed. American Journal of Veterinary Research 66: 413-417.

30. Ongerth, E and Sibbs H (1989) : Prevalence of Cryptosporidium infection in dairy calves in Western Washington. American Journal of Veterinary Research 50:1069-1070.

31. Park JH, Guk SM, Han ET, Shin EH, Kim JL and Chai JY (2006). Genotype analysis of Cryptosporidium spp. prevalent in a rural village in Hwasun- gun, Republic of Korea. Korean Journal of Parasitology 44(1):27-33.

32. Paul S, Chandra D, Tewari AK, Banerjee PS, Ray DD, Raina OK and Rao JR (2009). Prevalence of Cryptosporidium andersoni, a molecular epidemiological survey among cattle in India. Veterinary Parasitology, 161: 31-35.

33. Rehaman, ASMH, Sanyal SC, Al-Mahmud KA and Sobhan A (1985). Cryptosporidium diarrhoea in calves and their handlers in Banngladesh. Indian Journal of Medical Research. 82, 510-516.

34. Roy SS, Pramanik AK, Batabyal S, Sarkar S, Das P (2006): Cryptosporidiosis an important zoonotic disease: a review article. Intas polivet, 7:432-436.

35. Saini PK, Ransom G, and McNamara AM (2000). Emerging public health concerns regarding cryptosporidiosis. Journal of the American Veterinary Medical Association. 217: 658-663.

36. Samad MA, Haque AKMF, Rahman A, Ali KM and Sen MM (1977). Clinico-pathological report of an acute outbreak of monieziasis in calves. Bangladesh Veterinary Journal 11: 81-84

37. Samad MA, Taleb MA, Kader MA and Saha S (2001). Epidemiological studies on calf diseases associated with morbidity and mortality on large and small holder traditional farms in Bangladesh. Bangladesh Veterinary Journal 35: 121-129

38. Sayers GM and Dillon MC, Connolly E, Thornton L, Hyland E, Loughman E, O'Mahony MA and Butler KM (1996). Cryptosporidiosis in children who visited an open farm. Communicable Disease Report. 6, R140-R143.

39. Schindler AR, Abs El-Osta YG, Stevens M, Sinclair MI, and Gasser RB (2005). Capillary electrophoretic analysis of fragment length polymorphism in ribosomal markers of Cryptosporidium from humans. Molecular and Cellular Probes. 19(6):394-9.

40. Shovamani B (2005) Epidemiological studies on diarrhoea in calves with particular reference to diagnosis and treatment of cryptosporidiosis. Journal of Veterinary Parasitology 19: 77.

41. Spano F and Crisanti C (2000). Cryptosporidium parvum: the many secrets of small genome. Indian Journal of Parasitology. 30: 553-565.

42. Swai ES and Schoonman L (2010): Investigation into the prevalence of Cryptosporidium infection in calves among small-holder dairy and traditional herds in Tanzania. Veterinary Medicine International http://dx.doi.org/10.4061/2010/676451.

43. Tzipori SR, Campbell I and Angus KW (1982). The therapeutic effect of 16 antimicrobiological agents on infection in mice. The Australian journal of experimental biology and medical science 60: 187.

44. Webster KA (1993). Molecular methods for the detection and classification of Cryptosporidium. Parasitology Today 9: 263-266.

45. Xiao L, Escalante L, Yang C, Sulaiman I, Escalante AA and Montali RJ (1999). Phylogenetic analysis of Cryptosporidium parasites based on the small-subunit rRNA gene locus. Applied and Environmental Microbiology 65(4):1578-83.

47. Xiao L, Fayer R, Ryan U and Upton SJ (2004b). Cryptosporidium taxonomy: recent advances and implications for public health. Clinical Microbiology 17: 72-97.

48. Xiao L, Ryan UM, Graczyk TK, Limor J, Li L, Kombert M, Junge R and Sulaiman IM., Zhou L, Arrowood MJ, Koudela B, Modry D, Lal AA (2004a). Genetic diversity of Cryptosporidium spp. in captive reptiles. Applied and Environmental Microbiology 70: 891-899. 